\title{
A Tetrairon Dication Featuring Tetraethynylbenzene Bridging Ligand: a Molecular Prototype of Quantum-Dot Cellular Automata
}

\author{
Rim Makhoul, Paul Hamon, Thierry Roisnel, Jean-René Hamon, ${ }^{*}$ and Claude Lapinte*

\begin{abstract}
Univ Rennes, CNRS, ISCR (Institut des Sciences Chimiques de Rennes)-UMR 6226, F-35000 Rennes, France
E-mail: jean-rene.hamon@univ-rennes1.fr, claude.lapinte@univ-rennes1.fr

Supporting information for this article is given via a link at the end of the document.
\end{abstract}

\begin{abstract}
Cp}^{*}(\mathrm{dppe}) \mathrm{FeC} \equiv \mathrm{C}\right.\right.$ \}$\left._{4}-\mu-\left(1,2,4,5-\mathrm{C}_{6} \mathrm{H}_{2}\right)\right]\left(\mathrm{PF}_{6}\right)_{2}$ (1) was obtained through a sequence of three reactions from 1,2,4,5-tetraethynylbenzene, $\mathrm{Cp}^{*}(\mathrm{dppe}) \mathrm{FeCl}$ $\left(\mathrm{Cp}^{*}=\mathrm{C}_{5} \mathrm{Me}_{5}\right.$, dppe $=1,2$-bis (diphenylphosphino)-ethane), $\mathrm{KOBu}^{t}$, and ferrocenium hexafluorophosphate. The cyclic voltammogram of the target molecule isolated in $77 \%$ yield, exhibits four well separated and reversible redox events showing that 1 is thermodynamically stable with respect to disproportionation $(K \mathrm{C}>$ $10^{6}$ ). The tetranuclear dication 1 was characterized by XRD on single crystal, IR and NMR spectroscopies and Mössbauer spectrometry. The experimental data show that 1 behaves as a class II mixed-valence complex with the positive charges preferentially disposed on antipodal positions. This new molecule can be regarded as a potential molecular prototype of quantum-dot cellular automata.
\end{abstract}

Molecular electronics is based on the development of molecules designed to accomplish the role of diode or transistor at the molecular level. ${ }^{[1]}$ Alternatively, It has been proposed to use molecules, not as current switches, but as structured charge containers named quantum-dot cellular automata (QCA) for encoding binary information. ${ }^{[2]}$ Typically, a molecular QCA is composed of four dots - four redox centers at the molecular level - and two mobile electrons localized on antipodal sites to minimize Coulombic repulsion (Figure 1). ${ }^{[3]}$
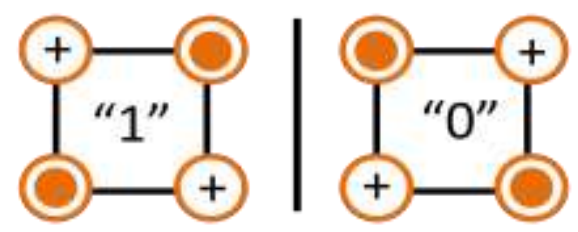

Figure 1. Schematic representation of a QCA cell encoding "1" and "0".

The realization of viable molecular QCA requires a good balance between essential properties: (i) strong enough electronic interactions between the redox centers to provide a sufficient thermodynamic stability to the two-charge carrier with respect to the disproportionation. This is a necessary requirement to allow the preparation and isolation of the molecular cell; (ii) from a physical point of view, the basic model of a molecular cell requires the Coulomb repulsion of the electrons in different electronic distributions among the redox sites, the electron transfer between the redox centers and the interaction of the itinerant electrons with molecular vibrations to ensure the trapping of the charge. ${ }^{[4-6]}$ Logically, the interest for QCA paradigm has sparked synthetic efforts for preparing tetranuclear inorganic complexes with four redox active sites with a square-like arrangements. Due to either too weak or too strong intermetallic interactions, these compounds do not meet all the required properties for the realization of viable QCA. ${ }^{[7-16]}$

Stimulated by our recent work on the preparation of the binuclear 1,2-diethynylbenzene-bridged complexes $\left[\left\{\mathrm{Cp}^{*}(\mathrm{dppe}) \mathrm{FeC} \equiv \mathrm{C}-\right\}_{2}-\mu-\left(1,2-\mathrm{C}_{6} \mathrm{H}_{4}\right)\right]\left(\mathrm{PF}_{6}\right)_{\mathrm{n}}\left(\boldsymbol{o}-\mathbf{2}\left(\mathrm{PF}_{6}\right)_{\mathrm{n}}, n=0-2\right),{ }^{[17]}$ we decided to prepare the novel tetrairon dicationic complex $\left[\left\{\mathrm{Cp}^{*} \text { (dppe) } \mathrm{FeC} \equiv \mathrm{C}-\right\}_{4}-\mu-\left(1,2,4,5-\mathrm{C}_{6} \mathrm{H}_{2}\right)\right]\left(\mathrm{PF}_{6}\right)_{2}$ (1). In addition, consideration of the electronic properties of the related binuclear compounds in which the redox centers are connected on the phenyl ring in the $1,3-\left(\boldsymbol{m}_{-2}\left(\mathbf{P F}_{6}\right)_{\mathrm{n}},{ }^{[18]}\right.$ and $1,4-\left(\boldsymbol{p}-\mathbf{2}\left(\mathbf{P F}_{6}\right)_{\mathbf{n}}\right.$ positions ${ }^{[19]}$ we could anticipate that complex 1 should be stable with respect to the disproportionation and consequently constitutes a viable synthetic target.

The complex 1 was synthesized from freshly prepared 1,2,4,5tetraethynylbenzene (ca. $0.5 \mathrm{mmol}$ ) and $\mathrm{Cp}^{*}$ (dppe) $\mathrm{FeCl}(5.2$ equiv) in triethylamine in the presence of $\mathrm{NaBPh}_{4}$ (5.2 equiv), (Scheme 1). The reaction is rather slow and takes $48 \mathrm{~h}$ to reach completion. The mixture was then treated with $\mathrm{KOBu}^{t}(5.2$ equiv). Washing with methanol and diethyl ether and extraction with toluene gave a brown powder. Immediate treatment with 2 equiv of ferrocenium hexafluorophosphate in THF provided compound 1 isolated as a purple powder in $77 \%$ yield. Slow diffusion of pentane into a saturated $\mathrm{CH}_{2} \mathrm{Cl}_{2}$ solution of 1 afforded black-purple crystals of the complex in a pure form. Complex 1 was characterized by XRD analysis on single crystals, elemental and mass analyses, IR, and paramagnetic NMR spectroscopies, Cyclic voltammetry, and Mössbauer spectrometry (see supporting information).

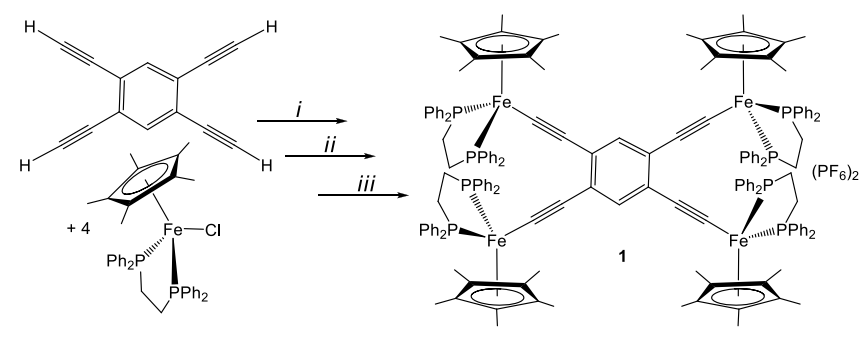

Scheme 1. Preparation of 1. key reagents: (i) $\mathrm{NaBPh}_{4}, \mathrm{NEt}_{3}$; (ii) $\mathrm{KOBu}^{t}$; (iii) $\left[\left(\mathrm{C}_{5} \mathrm{H}_{5}\right)_{2} \mathrm{Fe}\right]\left(\mathrm{PF}_{6}\right)$ (2 equiv). 
Crystals of $\mathbf{1}$ were suitable for X-ray analysis. Diffraction parameters are given in the supporting information (Table S1) and an ORTEP view is shown in Figure 2. Compound 1 crystallizes in the $P_{-1}$ triclinic space group and the asymmetric unit contains two crystallographically independent dicationic entities and four $\mathrm{PF}_{6}$ anions (1A and $\mathbf{1 B}$ ), along with strongly disordered crystallization solvent molecules $\left(\mathrm{CH}_{2} \mathrm{Cl}_{2}\right)$. Each dication comprises four $\mathrm{Cp}^{*}(\mathrm{dppe}) \mathrm{FeC} \equiv \mathrm{C}$ fragments and the steric hindrance among them is evidenced by a deviation from linearity of the $\mathrm{Fe}-\mathrm{C} \equiv \mathrm{C}-\mathrm{C}_{\mathrm{Ar}}$ axes (see Table S3, Supporting Information). The central phenyl ring remains planar, but the iron atoms are alternatively located above and below this plane. Formally, compound $\mathbf{1}$ is a mixed-valence (MV) complex with two $\mathrm{Fe}(\mathrm{II})$ and two Fe(III) centers. However, the Fe-P distances are not significantly different from one site to the other and the averaged Fe-P bond length $(2.207 \AA)$ is intermediate between the Fe-P distances expected for authentic $\mathrm{Fe}$ (II) and $\mathrm{Fe}$ (III) sites (2.17 and $2.27 \AA$, respectively). ${ }^{[20,21]}$ Therefore, the $\mathrm{Fe}(\mathrm{II})$ and $\mathrm{Fe}$ (III) sites cannot be distinguished by XRD analysis. The charges can be either delocalized over the four iron sites of the molecules or the $\mathrm{Fe}(\mathrm{II})$ and $\mathrm{Fe}(\mathrm{III})$ sites might be disordered in the crystal lattice.

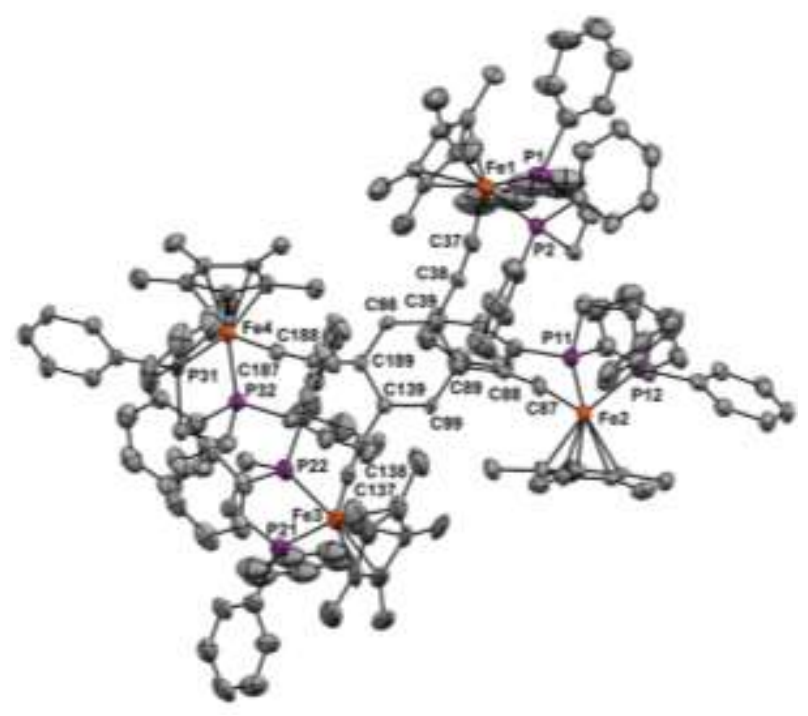

Figure 2. Molecular structure of 1A showing the atomic labelling. Hydrogen atoms, counteranions and solvent molecules have been removed for clarity. Thermal ellipsoids are drawn at $50 \%$ probability.

More informative are the $\mathrm{C}-\mathrm{C}$ bond distances in the central phenyl ring (Table S2, Supporting Information). The average for molecules 1A and 1B of the C39/239-C89/289 and C139/339C189/389 bonds lengths are significantly longer (ca. $1.48 \AA$ ) than the four other bonds of the ring (ca. $1.39 \AA$ ), indicating a possible quinoidal structure for the aromatic ring. In addition, in the limit of the accuracy of the X-ray data, the Csp-CAr bond distances seems to be slightly longer along one diagonal than along the other one, in accord with the localization of the charges on two antipodal iron centers (structures $A$ and $A^{\prime}$, Scheme 2) rather than a full delocalization on the four redox centers (structure B, Scheme 2).

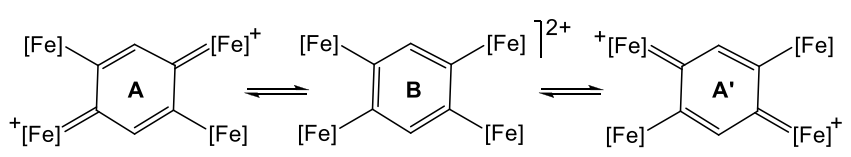

$[\mathrm{Fe}]=C p^{*}(\mathrm{dppe}) \mathrm{FeCC}$

Scheme 2. Possible electronic structures for 1 .

The IR spectrum of 1 (ground single crystals, $\mathrm{KBr}$ ) is characterized by two $\mathrm{v}_{\mathrm{C} \equiv \mathrm{C}}$ bands at 1961 and $1910 \mathrm{~cm}^{-1}$ and one shoulder at $1870 \mathrm{~cm}^{-1}$ (Figure S1, Supporting Information). The two bands at higher energy could be assigned to the $\mathrm{Fe}(\mathrm{II}) \mathrm{C} \equiv \mathrm{C}$ and $\mathrm{Fe}(\mathrm{III}) \mathrm{C} \equiv \mathrm{C}$ modes of vibration, respectively. ${ }^{[17]}$ Similar frequencies were found for the ortho disubstituted class II mixedvalence complex $\left[\left\{\mathrm{Cp}^{*}(\mathrm{dppe}) \mathrm{FeC} \equiv \mathrm{C}-\right\}_{2}-\mu-\left(1,2-\mathrm{C}_{6} \mathrm{H}_{4}\right)\right]\left(\mathrm{PF}_{6}\right) \quad$ (o2(PF $), v_{C \equiv C}=1977$ and $\left.1912 \mathrm{~cm}^{-1}\right) \cdot{ }^{[17]}$ In the case of the disubstituted binuclear relatives $\boldsymbol{m - 2}\left(\mathbf{P F}_{6}\right)$ and $\boldsymbol{p}-\mathbf{2}\left(\mathbf{P F}_{6}\right),{ }^{[18,19]}$ two $\mathrm{V}_{\mathrm{C} \equiv \mathrm{C}}$ bands were also observed, but at much higher energy. The IR data are consistent with the presence of $\mathrm{Fe}$ (II) and $\mathrm{Fe}$ (III) alkynyl fragments in vicinal positions. The shoulder at $1870 \mathrm{~cm}^{-1}$ is typical of 1 and bands in the $1800-1900 \mathrm{~cm}^{-1}$ range were not observed in the case of the mono- and dicationic binuclear analogues $\boldsymbol{o - 2}\left(\mathbf{P F}_{6}\right)_{\mathbf{n}}, \boldsymbol{m}-\mathbf{2}\left(\mathbf{P F}_{6}\right)_{\mathrm{n}}$, and $\boldsymbol{p}-\mathbf{2}\left(\mathbf{P F}_{6}\right) \mathbf{n}(n=1,2)$. This band might result from conjugated electronic structures $\mathbf{A}$ and $\mathbf{A}^{\prime}$ (Scheme 2). The IR spectrum of $\mathbf{1}$ obtained from a polycrystalline sample is slightly different (see Figure $\mathrm{S} 1$, Supporting Information). In particular, the shoulder at $1870 \mathrm{~cm}^{-1}$ has almost disappeared and a new shoulder at $2008 \mathrm{~cm}^{-1}$ is now visible on the spectrum. The structural changes associated with these spectroscopic modifications are difficult to analyze. However, IR and Mössbauer spectroscopies consistently suggest that the samples contains molecule $\mathbf{1}$ under two different forms.

Surprisingly, The ${ }^{1} \mathrm{H},{ }^{31} \mathrm{P}$, and ${ }^{13} \mathrm{C}$ NMR spectra obtained for 1 are well-resolved and show narrow lines at positions expected for a diamagnetic compounds (see Figures S2-S5, Supporting Information). Apparently $\mathbf{1}$ behaves as a diamagnetic compound. Indeed, for the bisiron(III) complexes, the chemical shift of the protons is very sensitive to the magnetic exchange coupling. ${ }^{[22]}$ For example, in the case of the binuclear complexes $p-2\left(\mathrm{PF}_{6}\right)_{2}$ and $\boldsymbol{m}-\mathbf{2}\left(\mathbf{P F}_{6}\right)_{2}$ for which a diradicaloid character dominates the valence-bond description of the electronic structure, the protons of the $\mathrm{Cp}^{*}$ ligands were found at $\delta-4.9 \mathrm{ppm}$ and $-10.9 \mathrm{ppm}$, respectively. ${ }^{[23,24]}$ In the case of $\mathbf{1}$, the resonance corresponding to these proton $(\delta=1.55 \mathrm{ppm}$ ) is very similar to that found for the diamagnetic bisiron(II) compound $o-2(\delta=1.54 \mathrm{ppm}),{ }^{[17]}$ suggesting that the two unpaired electrons are strongly antiferromagnetically coupled. As such magnetic exchange interaction is controlled by the topology of the charge carriers. ${ }_{-}{ }^{23}$ 24] It can only takes place if the Fe(III) sites are located on antipodal positions

The initial scan in the cyclic voltammetry of $\mathbf{1}$ run in dichloromethane from $-1.0 \mathrm{~V}$ to $1.0 \mathrm{~V}$ [vs standard calomel electrode (SCE)] is characterized by four resolved and reversible

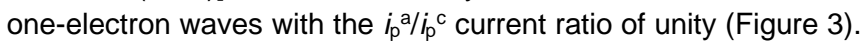
The electrochemical potentials are collected in Table 1 with those previously reported for the binuclear compounds $\mathbf{m - 2}, \boldsymbol{p}-\mathbf{2}$, and $\mathbf{0 - 2}$. In comparison with these complexes, the first oxidation potential of $\mathbf{1}$ is dramatically shifted toward negative potentials by around $0.5 \mathrm{~V}$. 


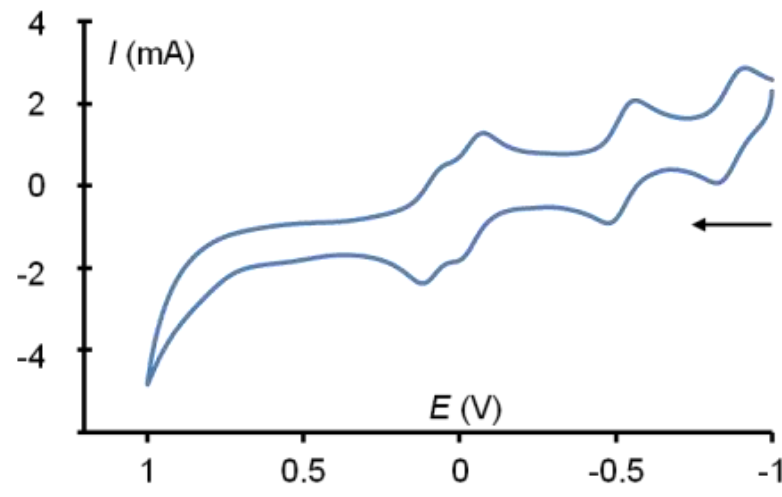

Figure 3. Cyclic voltammogram of $\mathbf{1}$ (conditions are given in Table 1 caption.

The second oxidation potential is also strongly cathodically shifted, while the potentials of the third and fourth oxidation processes showed more usual values for compounds of the $\mathrm{Cp}^{*}$ (dppe)FeC $\equiv \mathrm{C}$ family. ${ }^{[20,21]}$ The separations between the three first redox events are large $(0.36 \mathrm{~V}$ and $0.47 \mathrm{~V}$, respectively). Consequently, the comproportionation constants for the two equilibria involving the dicationic species 1 are very large $\left(K \mathrm{c}_{1}=1.01 \times 10^{6}, K \mathrm{C}_{2}=1.17 \times 10^{8}\right)$ and the dicationic complex is thermodynamically very stable in solution.

Table 1. Comparison of the electrochemical potentials for $\mathbf{1}$ and $\mathbf{m - 2}, \mathbf{p - 2}$, and o-2.

\begin{tabular}{llllll}
\hline Compd $^{[a]}$ & $\mathrm{E}^{0}{ }_{1}$ & $\mathrm{E}^{0}$ & $\mathrm{E}^{0}{ }_{3}$ & $\mathrm{E}^{0}$ & ref \\
\hline $\mathbf{1}$ & -0.77 & -0.41 & 0.06 & 0.18 & {$[\mathrm{~b}]$} \\
$\mathbf{0 - 2}$ & -0.37 & 0.00 & & {$[17]$} \\
$\boldsymbol{m - 2}$ & -0.23 & -0.10 & & [25] \\
$\boldsymbol{p - 2}$ & -0.27 & -0.01 & & {$[22]$} \\
\hline
\end{tabular}

[a] Potentials in $\mathrm{CH}_{2} \mathrm{Cl}_{2}\left(0.1 \mathrm{M} \mathrm{Bu}_{4}{ }_{4} \mathrm{~N}\left(\mathrm{PF}_{6}\right), 25^{\circ} \mathrm{C}\right.$, platinum electrode, sweep rate $0.100 \mathrm{~V} \mathrm{~s}^{-1}$ ) are given in $\mathrm{V}$ vs SCE; the ferrocene-ferrocenium couple (0.46 V vs SCE) was used as an internal reference. [b] This work.

Zero field ${ }^{57} \mathrm{Fe}$ Mössbauer spectra were run at $80 \mathrm{~K}$ for samples of complex 1 prepared from both ground crystals and powders obtained by precipitations of a concentrated solutions of 1 in $\mathrm{CH}_{2} \mathrm{Cl}_{2}$ poured into a large amount of pentane under fast stirring. The spectrum obtained with the ground crystals which contain molecules in well-defined conformations (Figure S6, Supporting Information), displays a unique well-resolved doublet characterized by an isomeric shift (IS $=0.22 \mathrm{~mm} / \mathrm{s}$ ) similar to those generally obtained for the neutral and cationic $\left[\mathrm{Cp}^{*} \text { (dppe) } \mathrm{FeC} \equiv \mathrm{C}-\right]^{0 /+}$ fragments. ${ }^{[21]}$ The quadrupole splitting (QS $=1.34 \mathrm{~mm} / \mathrm{s}$ ) is intermediate between the values found for the $\mathrm{Fe}(\mathrm{II})$ and $\mathrm{Fe}(\mathrm{III})$ compounds showing that intramolecular electron transfers take place between the iron sites with an exchange rate much faster than the slow spectroscopic time scale $\left(k_{\mathrm{e}}>10^{9} \mathrm{~s}^{-1}\right) \cdot{ }^{[22,26]}$

In contrast, the polycrystalline sample is composed of molecules with various conformations. As a result, the Mössbauer spectrum displays three distinct doublets with relative spectral absorption areas in the $17 / 66 / 17$ ratio (Figure S7, Supporting Information). The two doublets with equivalent surface areas have QS parameters $(2.16$ and $1.00 \mathrm{~mm} / \mathrm{s})$ close to the values usually determined for $\mathrm{Fe}$ (II) and $\mathrm{Fe}$ (III) alkynyl complexes, respectively. They can be assigned to a trapped MV form with intramolecular exchange rate constant $k_{\mathrm{e}}<10^{6} \mathrm{~s}^{-1}$. $^{[17]}$ It is noteworthy to mention that the QS value found for the $\mathrm{Fe}$ (III) sites is at the higher limit of the values determined for $\left[\mathrm{Cp}^{*} \text { (dppe) } \mathrm{Fe}(\mathrm{III})\right]^{+}$fragments which generally range between 0.8 and $0.9 \mathrm{~mm} / \mathrm{s}^{[20,21]}$ Interestingly, the larger values - around 1.0 $\mathrm{mm} / \mathrm{s}$ were found for bisiron(III) complexes in the singlet ground state. ${ }^{[27]}$ This data is also strongly consistent with a strong antiferromagnetic coupling between the $\mathrm{Fe}$ (III) sites. The main doublet $(Q S=1.59 \mathrm{~mm} / \mathrm{s}$ ) corresponds to detrapped mixedvalence molecules similar to those present in the crystalline material. The Mössbauer spectrum of the polycrystalline sample is consistent with a solid solution containing both the trapped $\mathrm{Fe}(\mathrm{II})-\mathrm{Fe}$ (III) mixed-valence form and a detrapped component (Fe(averaged)) in the $1 / 2$ ratio. This behavior is essentially attributed to the relative orientations of the bridge and metal fragments. ${ }^{[22]}$

In conclusion, we found a straightforward access to the tetrairon dication $\quad\left[\left\{\mathrm{Cp}^{*}(\mathrm{dppe}) \mathrm{FeC} \equiv \mathrm{C}-\right\}_{4}-\mu-\left(1,2,4,5-\mathrm{C}_{6} \mathrm{H}_{2}\right)\right]\left(\mathrm{PF}_{6}\right)_{2} \quad$ (1), a particularly sterically crowded compound which has been isolated in good yield. The four iron alkynyl groups are connected by a benzene ring providing a very compact assembly favorable for coulombic repulsion between the positive charges. According to the redox potentials the dicationic species is thermodynamically stable with respect to the disproportionation. The IR data indicate that complex 1 belongs to the class II MV complexes as defined by Robin and Day. ${ }^{[28]}$ The NMR data consistent with a strong antiferromagnetic coupling between the spin/charge carriers suggest that the positive charges are preferentially located on the antipodal positions. The Mössbauer data allowed the observation of discrete $\mathrm{Fe}(\mathrm{II})$ and $\mathrm{Fe}(\mathrm{III})$ sites and showed that the charge mobility depends on the conformation of the molecules. Complex 1 constitutes an excellent candidate for a molecular cell and deserves to be the subject of further experimental scanning tunneling microscopy to observe electron localization at the single-molecule scale on metal surface.

\section{Acknowledgements}

The authors thank Drs T. Groizard and J.-F. Halet for helpfu discussions.

Keywords: organoiron $\bullet$ tetraethynylbenzene bridge $\cdot$ mixedvalence $\bullet$ charge container $\bullet$ QCA (quantum cellular automata)

[1] F. Gendron, T. Groizard, B. Le Guennic, J.-F. Halet, Eur. J. Inorg Chem. 2020.

[2] C. S. Lent, Science 2000, 288, 1597

[3] C. S. Lent, B. Isaksen, M. Lieberman, J. Am. Chem. Soc. 2003, 125, 1056.

[4] B. Tsukerblat, A. Palii, S. Aldoshin, Isr. J. Chem. 2020, 60, 1.

[5] A. Palii, S. Zilberg, A. Rybakov, B. Tsukerblat, J. Phys. Chem. C 2019, 123, 22614

[6] S. Zalis, B. Sarkar, C. Duboc, W. Kaim, Monatsh Chem 2009, 140, 765 
[7] J. Jiao, G. J. Long, F. Grandjean, A. M. Beatty, T. P. Fehlner, J. Am. Chem. Soc. 2003, 125, 7522.

[8] J. Jiao, G. J. Long, L. Rebbouh, F. Grandjean, A. M. Beatty, T. P. Felhner, J. Am. Chem. Soc. 2005, 127, 17819.

[9] V. N. Nemykin, G. T. Rohde, C. D. Barrett, R. G. Hadt, C. Bizzarri, P. Galloni, B. Floris, I. Nowik, R. H. Herber, A. G. Marrani, R. Zanoni, N. M. Loim, J. Am. Chem. Soc. 2009, 131, 14969.

[10] N. R. Erickson, C. D. Holstrom, H. M. Rhoda, G. T. Rohde, Y. V. Zatsikha, P. Galloni, V. N. Nemykin, inorg. Chem. 2017, 56, 4716.

[11] K. Tahara, N. Terashita, T. Akita, S. Katao, J. Kikuchi, K. Tokunaga, Organometallics 2015, 34, 299.

[12] K. B. Vincent, J. B. G. Gluyas, S. Gückel, Q. Zeng, F. Hartl, M. Kaupp, P. J. Low, J. organomet. Chem. 2016, 821, 40.

[13] M. Akita, Y. Tanaka, C. Naitoh, T. Ozawa, N. Hayashi, M. Takeshita, A. Inagaki, M.-C. Chung, Organometallics 2006, 25, 5261.

[14] A. Burgun, F. Gendron, P. A. Schauer, B. W. Skelton, P. J. Low, K. Costuas, J.-F. Halet, M. I. Bruce, C. Lapinte, Organometallics 2013, 32, 5015.

[15] K. Mishiba, M. Ono, Y. Tanaka, M. Akita, Chem. Eur. J. 2017, 23, 2067.

[16] M. SZteinert, B. Schneider, S. Dechert, S. Demeshko, F. Meyer, inorg. Chem. 2016, 55, 2363.

[17] R. Makhoul, H. Sahnoune, V. Dorcet, J.-F. Halet, J.-R. Hamon, C. Lapinte, Organometallics 2015, 34, 3314.

[18] T. Weyland, K. Costuas, L. Toupet, J.-F. Halet, C. Lapinte, Organometallics 2000, 19, 4228.

[19] S. I. Ghazala, F. Paul, L. Toupet, T. Roisnel, P. Hapiot, C. Lapinte, J. Am. Chem. Soc. 2006, 128, 2463.

[20] F. Paul, C. Lapinte, Coord. Chem. Rev. 1998, 178-180, 427.

[21] J.-F. Halet, C. Lapinte, Coord. Chem. Rev. 2013, 257, 1584.

[22] N. Le Narvor, C. Lapinte, Organometallics 1995, 14, 634.

[23] T. Weyland, K. Costuas, A. Mari, J.-F. Halet, C. Lapinte, Organometallics 1998, 17, 5569.

[24] F. Paul, A. Bondon, G. Da Costa, F. Malvoti, S. Sinbandit, O. Cador, K. Costuas, L. Toupet, M. L. Boillot, Inorg. Chem. 2009, 48, 10608.

[25] T. Weyland, C. Lapinte, G. Frapper, M. J. Calhorda, J.-F. Halet, L. Toupet, Organometallics 1997, 16, 2024.

[26] S. Le Stang, F. Paul, C. Lapinte, Organometallics 2000, 19, 1035.

[27] V. Guillaume, V. Mahias, A. Mari, C. Lapinte, Organometallics 2000, 19, 1422.

[28] M. B. Robin, P. Day, Adv. Inorg. Chem. Radiochem. 1968, 10, 247. 


\section{Entry for the Table of Contents}

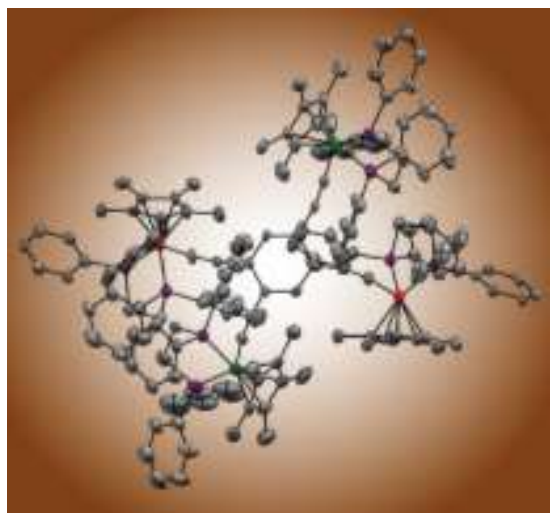

A novel tetranuclear iron dicationic complex has been synthesized and isolated as a hexafluorophosphate salt. The dicationic moiety constitutes a structured charge container able to encode binary information in the charge configuration. It constitutes a QCA cell. The IR data are characteristic of a class II mixed-valence complex, while the physical properties are consistent with a localization of the positive charges on the antipodal positions to minimize Coulomb repulsion and favour antiferromagnetic exchange coupling.

Twitter usernames: https://twitter.com/chimie iscr 